two explanations that have been advanced, that of Neumayr, who considered the special features due to climatic influences, and that of Pompeckj and Salfeld, who explained them as the result of life in an isolated sea with unusual physical peculiarities. The author considers that the fauna was mainly controlled by growth in a special sea in which there was great continuity of evolution. He says that the isolation which he accepts is quite different from that contemplated by Pompeckj and Salfeld.

That complete separation from the other seas would affect its inhabitants is undoubted; but in view of the parallel development of the faunas in the Spitsbergen sea with those that lived farther south, some frequent connexions appear to have taken place. The peculiar features of the Spitsbergen fauna, when compared with those of England, the Mediterranean and the Himalaya, appear to indicate the influence of a colder climate than that enjoyed by the Jurassic areas farther south.

Hans Trebold has also written Memoir, No. 21, a description of the Valanginian Ammonites of Spitsbergen, a fauna which is similar to that of the Petchora basin in north-eastern Russia and has some of the species found in the Speeton Clay of Yorkshire.

The most remarkable addition to palæontology in this series of memoirs is the rich fauna of fossil Acanthaspid fish described by Anatol Heintz from the
Downtonian. $\mathrm{He}$ includes that formation in the Lower Devonian, but it has been usually regarded as uppermost Silurian. The fauna described in the first Memoir, No. 22, is from Ice Fiord, and it includes three new families and seven new genera. The type of the new genus, Jaekelaspis, is a species described by Ray Lankester as a Cephalaspis and by Sir Arthur Smith Woodward as an Acanthaspis. The affinities of these fish have been uncertain. Lankester and Sir Arthur Smith Woodward regarded them as belonging to the primitive class of Agnatha; but Traquair referred them to the fish as Dipnoi and members of the Arthrodira. That view is adopted by Herr Heintz. The second Memoir, No. 23, describes some additional new species of Acanthaspids, including a remarkable new form, Huginaspis broggeri, from the Downtonian of Wijde Fiord in north-western Spitsbergen. These two memoirs form a material addition to knowledge of this group.

The other Palæozoic fossil described in this new series is a simple coral, Caninia $(C$. callophylloides, Holtedahl sp.), from the Carboniferous of Ice Fiord. The coral is described in detail by F. Heritsch, and heclearly states the relations of the genus to Zaphrentis. The largest radius in the biggest specimen is $27 \mathrm{~mm}$. There is nothing in this coral to call for any special climatic conditions in the Arctic Sea at the time of its existence.

\title{
Experiments in the Sea on Antifouling Paints.
}

DROF. J. H. ORTON (Jour. Mar. Biol. Assoc., N.S., vol. 16, No. 2, 1930) describes the results of a series of experiments, extending over a period of three and a half years, to test the power of a number of paints and other substances (fifteen in all) to inhibit the growth of marine organisms, their preservation value, and their durability in sea water. The experimental material included proprietary antifouling and anticorrosive paints and was tested in seven different habitats in three different localities on wood and on shells. Observations were also made on the growths on ships' bottoms, piers, buoys, and rafts.

It was found that the fundamental factors determining the capacity of a paint to prevent growths include (a) capacity to adhere to a surface, which in practice may be slightly damp ; (b) capacity to resist erosion; and $(c)$ the possession of a toxicity depending upon slow but efficient ionisation of toxic substances. It is proved by critical chemical analyses that gradual loss of toxicity of the more efficient poisonous paints was accompanied by gradual diminution of the toxic elements, arsenic, copper, and zine, in the paints. Antifouling paints exposed to strong light permit the growths much sooner than in subdued light, but, in the former case, the growth is marine algæ. It is not clear whether this phenomenon is due to the loss of toxicity in the paint due to the direct action of light, or to a greater resistance of the spores of marine algæ to toxic agents.

The preserving value of antifouling substances was also investigated, and it is shown that, for wood at least, coal-tar and black varnish have superior preservative properties to red oxide of iron, the commonest and most widely used anticorrosive paint for the bottoms of iron ships. Coal-tar and black varnish will preserve wood against Chelura and Limnoria, but not against T'eredo, to an extent at least equal to that ensured by red oxide, but, on the other hand, they give innocuous surfaces on which marine growths establish themselves more readily than on untreated wood.

The composition of an ideal antifouling paint is discussed and the conclusion reached that if the bottoms of ships are to be maintained free from growths for a period stated in years, some other method must necessarily be used than the application of paints, owing to the comparatively rapid disintegration of the matrix of the paint due to the action of bacteria.

\section{Ceylon Pearl Fisheries.}

A MOST interesting memoir entitled "The Pearl A Fishery of 1925 " by Dr. Joseph Pearson, assisted by Mr. A. H. Malpas and Mr. J. C. Kerkham, is given in the Ceylon Journal of Science (Section C, Fisheries, Bulletin of the Ceylon Fisheries, vol. 3, December 1929). It includes a review of the scientific investigations since 1902 and is directly concerned with the industrial problems and those of economic importance.

The outstanding features of the Ceylon pearl fisheries are their irregularity and uncertainty. After the fishery of 1891 , there was a barren interval of eleven years followed by five splendid fisheries in 1903-7, and after 1907 there was an interval of seventeen bad years before the fishery of 1925 ; making only six fisheries since 1891 - a period of thirty-four years.

No. 3174, VoL. 126]
The establishment of a Department of Fisheries, with the appointment of a marine biologist, provision of a modern steam trawler, and the regular inspection of the pearl banks, have made possible a survey of the littoral waters of Ceylon, and much is now known of the biology of the coastal waters in general and of the pearl-banks in particular. The investigations carried on since the War have been restricted to the inspections, supplemented by trawling and dredging operations and to periodic hydrographical cruises in the Gulf of Mannar.

The situation of the pearl-banks area, with its hundreds of square miles of deep water, its lack of protection from the violence of the south-west monsoon, and a complete lack of a suitable situation in which to establish a 'nursery', makes cultural work 